DOI: $10.17951 / 1 r p .2019 .38 .1 .277-293$

\author{
MaRCin CABAK \\ Wydział Pedagogiki i Psychologii UMCS \\ https://orcid.org/0000-0001-7885-4813
}

\title{
WARSZTAT TWÓRCZY \\ JAKO METODA EDUKACJI ARTYSTYCZNEJ NA WYDZIAŁACH NIEARTYSTYCZNYCH
}

\begin{abstract}
Streszczenie: W artykule podjęto problematykę zastosowania warsztatu twórczego jako metody dydaktycznej w edukacji artystycznej na wydziałach nieartystycznych. W pierwszej części analizowane jest na podstawie literatury pojęcie warsztatu twórczego jego geneza, historia, umiejscowieni w przestrzeni sztuki, oraz dylematy związane z zastosowaniem go w warunkach wydziałów innych niż artystyczne. Drugą część stanowi opis przeprowadzonych w warunkach nieartystycznej uczelni wyższej działań warsztatowych. Trzecia zawiera wnioski. W części czwartej prezentowane są przykładowe wytwory powstałe w czasie warsztatu.
\end{abstract}

Słowa kluczowe: warsztat twórczy, dydaktyka, metody dydaktyczne

\section{WPROWADZENIE}

Warsztat twórczy jako metoda edukacyjna ma w Polsce kilkudziesięcioletnią tradycję. Obecnie z powodzeniem funkcjonuje jako jedna z propozycji prowadzenia zajęć na uczelniach i wydziałach artystycznych. W artykule autor na podstawie analizy literatury oraz doświadczeń własnych przedstawia możliwość zaadaptowania tej metody do edukacji artystycznej na wydziałach innych niż artystyczne.

\section{CZYM JEST WARSZTAT TWÓRCZY?}

Analizując sposób funkcjonowania nazwy warsztat twórczy" w literaturze, można dojść do wniosku, że ukrywa się pod nią co najmniej kilka odmiennych pojęć. 
Może być więc warsztat twórczy rozumiany jako zbiór cech charakterystycznych dla stylu wypowiedzi artystycznych określonego artysty (zob. np. Józefowski, Florczykiewicz 2015b). Warsztat twórczy jest rozumiany także jako zespół cech, umiejętności, kompetencji, wiedzy, sposobów pracy właściwy dla konkretnego twórcy (zob. np. Buchner, Maryl, 2015). Po trzecie oznacza on pewien rodzaj ulotnych, interaktywnych działań artystycznych zapoczątkowanych w XX w. w USA, zaliczanych do sztuki nowoczesnej lub też może być określeniem „działań, których istotą jest rozwijanie twórczości poprzez aktywne uczestnictwo w proponowanych zadaniach" (Józefowski, Florczykiewicz 2015a, s. 55) - ta właśnie definicja będzie stanowiła podstawę dalszych rozważań, w trakcie których zostanie jednak dookreślona.

Zaletą podanej wyżej definicji jest to, że wydaje się mieścić wiele odmiennych od siebie w szczegółach, lecz zbliżonych w swej istocie poczynań. Daje ona jednak jedynie bardzo ogólny obraz opisywanego zjawiska. Aby lepiej zrozumieć, czym jest lub może być warsztat artystyczny, należy bliżej przyjrzeć się genezie samego pomysłu, jak również temu, co na jego temat mają do powiedzenia zarówno teoretycy, jak i sami autorzy/twórcy.

Z przeglądu literatury wynika, że koncepcja wykorzystania warsztatu twórczego jako sposobu oddziaływania o charakterze pedagogicznym w Polsce zrodziła się i została wypracowana w latach 70. i 80. mniej lub bardziej niezależnie w kilku grupach zrzeszających artystów poszukujących nowych środków wyrazu. Jan Berdyszak (2001, s. 9) wspomina działalność pracowni „Dziekanka” podjętą w latach siedemdziesiątych przez Janusza Bałdygę, Jerzego Onucha i Łukasza Szajnę, która w sposób programowy zajmowała się sztuką efemeryczną oraz inicjowaniem licznych form warsztatów artystycznych. Doświadczenia zdobyte w wyniku tych działań zaowocowały w latach 80. dostrzeżeniem i wykorzystaniem przez wspomnianych artystów pedagogicznego potencjału warsztatu w pracy z dziećmi i młodzieżą.

W tym samym czasie, jak piszą Józefowski i Florczykiewicz (2015b, s. 55), edukacyjne możliwości warsztatu stały się podstawą działalności grupy pARTner. Jej członkowie poszukiwali alternatywnych - w stosunku do tradycyjnych - metod edukacji artystycznej, a zwłaszcza możliwości zastosowania artystycznych środków wyrazu i działań z obszaru sztuki do rozwoju podmiotowego. W wyniku doświadczeń wykształciły się u poszczególnych twórców odmienne poglądy na sens i cele działań warsztatowych, a co za tym idzie - liczne autorskie ich koncepcje. Obecnie, śledząc wypowiedzi samych autorów, uznać można, że istnieje w zasadzie tyle koncepcji, ilu twórców warsztatów. Nie oznacza to jednak, że w tym bogactwie nie można znaleźć cech wspólnych.

Warto jednak wcześniej wspomnieć, że rozumienie warsztatu artystycznego jako aktywności edukacyjno-artystycznej, możliwe jest dzięki redefinicji wielu 
pojęć w obszarze sztuki, polegającej na zwiększeniu ich zakresu w stosunku do rozumień tradycyjnych, jakie dokonało się na skutek działań artystów awangardowych i postawangardowych. Poszerzenie to, będące charakterystyczną cechą sztuki współczesnej, zdaniem Berleanta (2007) polega przede wszystkim na rozbudowaniu skali percepcji dzieła przez zaangażowanie w ten proces większej ilości zmysłów, zmianie sposobu doznawania estetycznego polegającej na zmniejszeniu dystansu między twórcą, dziełem i jego odbiorcą oraz na intencjonalnym włączaniu w jego treść elementów życia codziennego.

Współczesne wytwory artystyczne niejednokrotnie wymagają od widza zaangażowania symultanicznie wielu zmysłów, w tym takich jak np. smak, zapach, dotyk, zmysł kinestetyczny, a jednocześnie zaangażowania się, wejścia w pewną sytuację, współtworzenia jej i dointerpretowania. Co za tym idzie, najważniejszą treścią przeżycia estetycznego, obok biernej kontemplacji, staje się współuczestniczące doświadczanie.

Inną ważną cechą sztuki postawangardowej jest silne zaakcentowanie procesualności aktu twórczego. Obecnie często to właśnie proces stanowi o istocie działania artystycznego, a materialny wytwór jaki w jego efekcie powstaje jest traktowany jedynie jako jego ślad lub zapis, a nawet całkowicie ignorowany. Można zatem powiedzieć, że dzisiaj w kreacji artystycznej samo „dzianie się” jest nierzadko co najmniej równorzędnym, o ile nie istotniejszym elementem w stosunku do jej ostatecznego efektu.

Wracając do samego warsztatu artystycznego, jak twierdzi Bałdyga (2016, s. 79) formuła ta jest ważną alternatywą dla tradycyjnych metod kształcenia w uczelniach. Według tegoż autora istotnymi cechami odróżniającymi warsztat od tradycyjnych metod edukacyjnych są jego relatywna krótkotrwałość oraz brak bezwzględnego dążenia do osiągnięcia założonych a priori rezultatów oraz nakierowanie na pobudzenie osobistych „uwolnionych od obowiązujących normatywów, doktryn, technik i specjalizacji” wypowiedzi uczestników (Bałdyga 2016, s. 79).

Podobnie koncepcja warsztatu E. Józefowskiego zakłada odrzucenie rygorów dzieła określonych przez jego strukturę artystyczną wyznaczaną przez wybór tej czy innej techniki. Wolność od apriorycznych założeń programowych jako istotną cechę warsztatu podkreślają również inni autorzy (zob. Byszewski 2001; Olinkiewicz 2001; Bałdyga 2016).

Według Byszewskiego psychologiczna i programowa dynamika działań warsztatowych podporządkowana jest nie tyle z góry przyjętemu scenariuszowi, ile wynika „Z niepowtarzalnej sytuacji, którą kreują uczestnicy.” Z kolei Olinkiewicz (2001, s. 11) podkreśla zarówno „potencjalność i „niekonieczność” działań warsztatowych jak i przewagę znaczenia procesualności tychże działań nad ich końcowym efektem. 
Dla Bałdygi obecność oraz jawność procesu twórczego kreują okazje do tworzenia nowego języka komunikacji oraz społecznych kontekstów stymulujących nowe relacje w zarówno w grupie warsztatowej jak i poza nią. Jawność - według niego - umożliwia także dotarcie do istoty dzieła na każdym etapie tworzenia, co czyni warsztat „skutecznym narzędziem edukacji i samoedukacji nawet wówczas, gdy nie towarzyszy nam konkretna intencja powołania procesu edukacyjnego." (Bałdyga 2016, s. 11). Jak twierdzi dalej cytowany autor „pracownia może wykształcić proces edukacyjny w formie dialogu wyabstrahowanego ze złożonych relacji społecznych".

Podobny pogląd wydaje się głosić Byszewski (2001, s. 22), gdy twierdzi, że działania warsztatowe mogą prowadzić do wytworzenia sytuacji niemożliwych do doświadczenia w życiu codziennym.

Również Józefowski określa warsztat jako alternatywny sposób zetknięcia się z rzeczywistością, dający szansę na niecodzienne doświadczanie siebie i relacji z innymi w odmiennej od codzienności przestrzeni sztuki (Józefowski, Florczykiewicz 2015b, s. 33).

Kolejnym znaczącym atrybutem działań warsztatowych podnoszonym przez licznych autorów jest ich „aktualność”, „dzianie się tu i teraz” w określonej przestrzeni i ograniczonym czasie. Ta swoista „jednorazowość" i efemeryczność działań warsztatowych wyznacza zdaniem Bałdygi (2016, s. 80) aktualny, a więc niepowtarzalny status zarówno twórcy, obserwatora, jak też miejsca i czasu. „Warsztat kreuje metodę silnie umocowaną w realnej przestrzeni i czasie" (Bałdyga 2001, s. 55).

Zaangażowaniu uczestników warsztatu w doświadczanie przestrzeni i czasu służyć ma - zdaniem wielu autorów - odmienne od tradycyjnych sytuacji edukacyjnych głębsze, polisensoryczne „dostrojenie się” do przeżywanej, a zarazem kreowanej rzeczywistości. Zdaniem Józefowskiego i Florczykiewicz (2013 s. 275) „intencją zadań złożonych na strukturę warsztatu jest zaangażowanie możliwie wszystkich sfer osobowości, dlatego w zamyśle organizowanej sytuacji twórczej uwzględnia się konieczność dostarczenia bodźców o różnorodnym charakterze: zmysłowych, emocjonalnych i poznawczych".

To „wejście” w konkretne miejsce i czas ma wzbogacać zarówno uczestników warsztatu, jak i przekształcać, „oswajać” zastaną przestrzeń. Jak pisze Olinkiewicz (2001, s. 91): „Doświadczamy przestrzeni poruszając się w niej. Dotykając poznajemy kształt i fakturę, wzbogacamy odczuwane miejsce." Wczytując się w powyższe wypowiedzi, można odnieść wrażenie, że zdaniem artystów wykorzystujących tę formę wyrazu, warsztat stwarza uczestnikom możliwość głębszego, pełniejszego doświadczania siebie w tu i teraz istniejących przestrzeni i czasie (zob. Olinkiewicz, Bałdyga, Byszewski i in.). Jak pisze Byszewski (2001, s. 21): „Te dwie kategorie: tutaj [wytłuszczenia oryginalne] (miejsce w którym jestem) oraz jestem (osoba, która 
działa i przekształca swoje duchowe i materialne środowisko) wyznaczają twórczą obecność w świecie”. Oraz dalej: „Powrót do tego co istnieje naprawdę, do tego kim jestem, wyznacza drogę człowieka do jego twórczych możliwości, w stronę twórczego, autentycznego zaistnienia w świecie". Tylko skoncentrowanie się na miejscu, w którym aktualnie jesteśmy i które coś dla nas znaczy, może sprawić, że weźmiemy za nie odpowiedzialność". Jednocześnie, jak twierdzi Olinkiewcz (2001, s. 11), warsztaty twórcze dają uczestnikom szansę twórczego wykorzystania zarówno już posiadanych informacji i doświadczeń, jak i tego, co stanowi dla nich obszar nowy i nieznany.

Pomimo odmienności autorskich koncepcji działań warsztatowych wszyscy wspomniani powyżej autorzy zgodni są co do tego, że warunkami koniecznymi do zaistnienia sytuacji warsztatowej są: symultaniczne współdziałanie pewnej grupy osób oraz niedyrektywność i demokratyzm objawiające się na każdym etapie i w różnych aspektach działań. Jak twierdzi Bałdyga (2016, s. 79) „Warsztat jest zdarzeniem edukacyjnym lub samokształceniowym realizowanym przez grupę powołaną do podjęcia działań w zazwyczaj krótkim, precyzyjnie określonym czasie [...] inicjowanym przez prowadzącego, który w pewnych warunkach może być traktowany jako lider i przewodnik, ale nie mistrz". W innym miejscu określa także warsztaty jako działanie zbiorowe, wymagają demokratycznego wypracowania strategii i metod działania, które z kolei obligują do współobecności oraz współodpowiedzialności wszystkich uczestników tworzących jednakże „zbiór autonomicznych osobowości, [...] o różnym stopniu zaangażowania, różnym stopniu świadomości i różnie sformułowanych celach i aspiracjach" (Bałdyga 2016, s.11).

Z kolei Berdyszak (2001, s. 9) pisze: „U podstaw istoty warsztatów leży zdolność do otwartej inicjacji, a może i charyzmat prowokującego prowadzącego i jego umiejętność przyznawania wolności twórczej uczestniczącym w warsztatach".

Według Olinkiewicz (2001, s. 11) warunkami sine qua non skutecznej praktyki warsztatowej są: dobrowolność uczestnictwa konieczna dla osiągnięcia autentyczności działań każdego z uczestników, brak reżimu czasowego (rozumianego przez autorkę, jak się wydaje, jako ramy czasowe mające źródło poza samą dynamiką działań - np. system dzwonkowy w szkole), dający możliwość wypowiedzi każdemu z uczestników w jego indywidualnym tempie, a także poczucie wolności i bezpieczeństwa. Myśli tak również Józefowski (2009, s. 10), gdy pisze: „Dobrowolność zabierania głosu, spontaniczność wypowiedzi, partnerstwo, podmiotowość traktowania uczestników, to część zasad postępowania”. Podobne wypowiedzi podkreślające wagę dobrowolności uczestnictwa, konieczności wyzwolenia się z różnego rodzaju ograniczeń codzienności można znaleźć także u wielu innych autorów.

Większość autorów silnie podkreśla także aspekt podmiotowego rozwoju uczestników zawarty w działaniach warsztatowych. Jak pisze Olinkiewicz (2001, 
s. 88) warsztaty działań twórczych są sposobem na wydobycie niepowtarzalnej osobowości każdego z uczestników, są „wyzwalającymi radość uczestnictwa ale i dramat tworzenia. Są spotkaniami opartymi na wyzwalaniu ekspresji, kształtowaniu aktywności, budzeniu wyobraźni, ale także dającymi możliwość spotkania [...] młodego człowieka z sobą samym i ze światem na wiele niekoniecznych sposobów. [...] Zmiana bierności na spontaniczną aktywność, tworzy motywację poznawczą, ciekawość i dążenie do samookreślenia. Odkrycie własnej indywidualności i tożsamości, możliwości przekraczania własnego ja”.

Podobnie wydaje się myśleć Berdyszak (2001, s. 10) gdy podkreśla, że: „Praktyka aktywności twórczej staje się wychowaniem sprawczym, niezaniedbywana może prowadzić do edukacji pojętej dynamicznie, rozwijającej różne osobowości i odmienne ich dyspozycje. Tak wyłaniane stany aktywności twórczej są niepowtarzalne - uczą dostrzegać i cenić zdarzenia oraz sytuacje jednorazowe i efemeryczne".

Jak twierdzą Józefowski i Florczykiewicz (2015a, s. 39-40): „warsztat jest symultanicznym działaniem kilku osób przy kreacji plastycznej, ukierunkowanym na intensyfikację podmiotowego doświadczenia sprzyjającego odczuciu podmiotowości". Przy okazji warto wspomnieć, że wymienieni autorzy dodatkowo uzasadniają wartość warsztatu twórczego jako pola rozwoju podmiotowego w wymiarach zarówno tożsamościowym, twórczym, poznawczym jak i emocjonalnym wynikami przeprowadzonych wspólnie (godnych osobnej uwagi) badań (zob. np. Józefowski, Florczykiewicz 2015a,b)

Reasumując powyższe wypowiedzi, można zauważyć, że najczęściej podnoszonymi cechami konstytutywnymi warsztatu artystycznego czy twórczego (obie nazwy wydają się funkcjonować zamiennie) są: jego relatywna krótkotrwałość, a jednocześnie wolność od ograniczeń czasowych brak dążenia do osiągnięcia z góry przyjętego efektu, dialogowość, „aktualność”, dobrowolność uczestnictwa, niedyrektywność i pewnego rodzaju „przezroczystość” osoby inicjującej, otwartość formy i treści, jawność procesu twórczego, jednorazowość rozumiana jako „zaistnienie” czy „dzianie się” w niepowtarzalnym „tu i teraz”, konkretnym miejscu i czasie, przeniesienie nacisku z efektu na proces oraz ukierunkowanie na rozwój podmiotowy uczestników.

Czy zatem możliwe jest spełnienie lub chociaż znalezienie sensownego kompromisu między wymienionymi cechami warsztatu twórczego a sytuacją, jaką stwarza dzisiaj szkoła wyższa (inna niż artystyczna), tak, aby włączyć go do repertuaru dydaktycznych poczynań? Już bowiem sama dobrowolność udziału może stwarzać pewien kłopot. Wszak spora część zajęć jest dla studentów obowiązkowa. Co z wolnością od ograniczeń czasowych? Przecież tryb w jakim odbywają się wykłady czy ćwiczenia można nazwać w zasadzie „dzwonkowym”. Jak ma się brak z góry określonego celu do założonych a priori efektów kształcenia? Czy możliwe 
jest w warunkach uczelnianych to „wycofanie się w cień”, „cicha jedynie obecność” nauczyciela lub wykładowcy?

Chęć odpowiedzi na powyższe pytania była bezpośrednim impulsem do dokonanej próby przeniesienia metod warsztatu twórczego na grunt uczelni nieartystycznej. Opis tych poczynań przeprowadzonych w ramach ćwiczeń z przedmiotu edukacja artystyczna z grupą pięćdziesięciu dwóch studentek i studentów kierunku Animacja Kultury na Wydziale Pedagogiki i Psychologii UMCS oraz próba ich interpretacji będą stanowiły dalszą część artykułu. Sam „warsztat” przyjął formę dziesięciu spotkań o zróżnicowanym czasie trwania (od $30 \mathrm{~min}$. do ponad dwóch godzin), o zróżnicowanej tematyce, połączonych jednak ideą realizacji jednego przedsięwzięcia artystycznego. Poniżej postaram się omówić w skrócie każde z zajęć cyklu.

\section{WARSZTAT TWÓRCZY „STONEOWANI”}

\section{INICJACJA WARSZTATU - KAMIEŃ NA DOBRY POCZĄTEK}

Wczytując się w wypowiedzi praktyków, można dojść do wniosku, że rozpoczynając warsztat artystyczny należy pogodzić dwa z pozoru sprzeczne podejścia. Z jednej strony punktem inicjującym, inspiracją warsztatu może być niemal wszystko, dowolny przedmiot, refleksja, idea, obraz, fragment tekstu itd. (zob. np. Olinkiewicz 2001, Bałdyga 2016 ). Z drugiej jednak strony zauważyć można, że wybór ten nie powinien być przypadkowy i ma za zadanie stwarzać okazję do jak najszerszej, swobodnej interpretacji przez każdego z uczestników. Takie podejście uzasadniają wnioski psychologów potwierdzające istotny pozytywny związek między niejednoznacznością a działaniem twórczym (zob. np. Popek 2003). Można zatem uznać, że początek warsztatu powinien być na tyle niejednoznaczny lub pojemny, aby w jak najmniejszym stopniu ograniczał możliwości wyboru dalszych działań, natomiast w możliwie największym stopniu sprzyjał ekspresji studentów. Takim pojemnym, niejednoznacznym, symbolicznie zawierającym w sobie możliwość wręcz antynomicznych skojarzeń jest kamień.

W myśl powyższych refleksji pierwszym zadaniem postawionym przed studentami było znalezienie kamienia, który z jakichś powodów, nieistotne jakich, byłby dla nich ważny. Nie został określony konkretny termin, w którym kamień taki miałby się odnaleźć poza prośbą, aby odbyło się to w jakimś sensownym czasie, tak, aby poszukiwanie własnego kamienia nie dezorganizowało pracy całej grupy. 


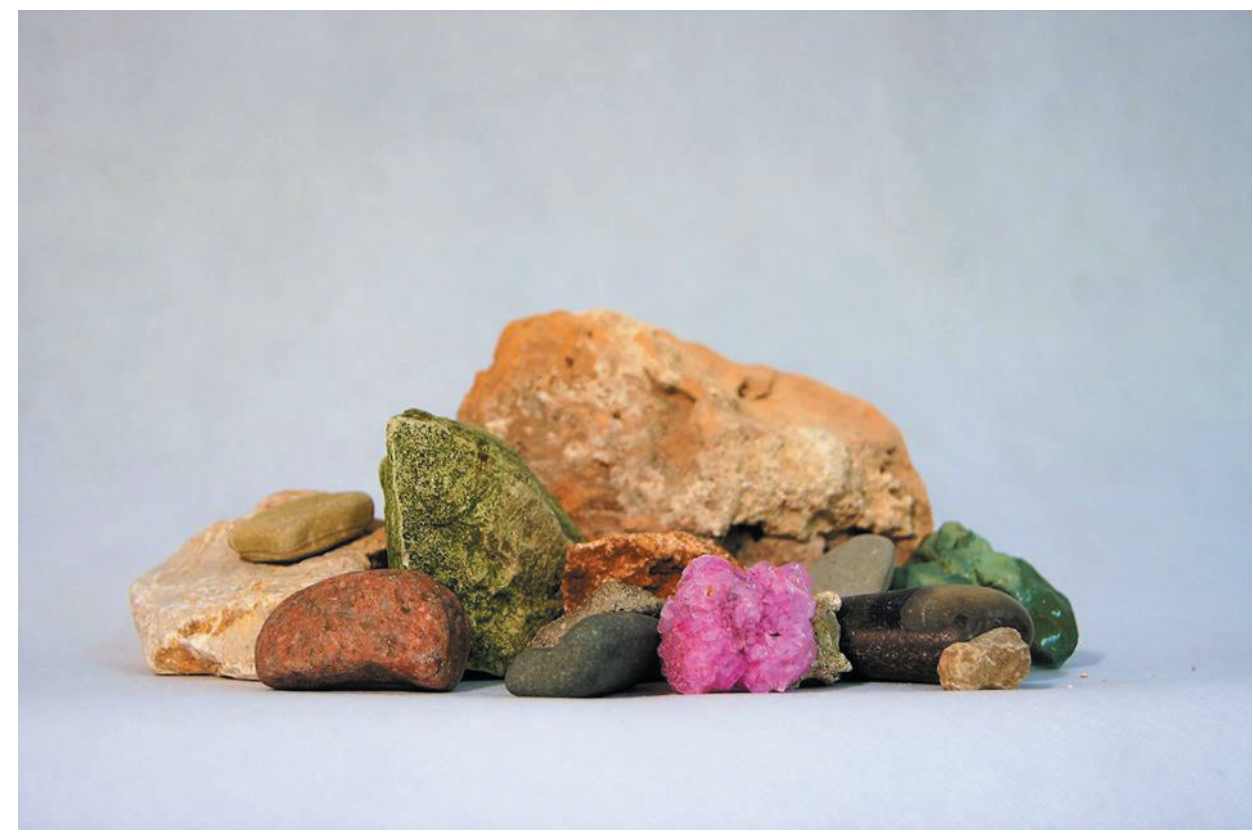

Fot. 1. Kamienie użyte w trakcie warsztatu - fot. Djana Berdak

\section{DZIEŃ DRUGI - W RĘKU KAMYK ZIELONY}

Pierwszy etap tego spotkania polegał na pracy z metaforą na podstawie wewnętrznego procesu opartego o własne fantazje, skojarzenia, wspomnienia, odczucia, obrazy, emocje, zainicjowane doświadczeniem polisensorycznym.

Kolejnym etapem była werbalizacja wewnętrznego procesu. Osoby, które wyraziły taką chęć, mogły podzielić się własnym doświadczeniem. Werbalizacja stanów emocjonalnych pozwoliła przejść od nieświadomego doświadczenia do świadomego przeżywania i ekspresji stanów emocjonalnych (Wawrzyniak 2002, s. 2). Artykulacja skojarzeń, obrazów, odczuć, osobistych symbolik, stanowiła wstęp do odkrywania potencjałów kraeacyjnych zawartych w kamieniu postrzeganym jako materialny przedmiot, budulec, ale także jako potencjalny symbol, metafora, nośnik idei czy przeżycia. W trakcie swobodnej wymiany myśli pojawiły się pomysły na stworzenie działań bliskich instalacji, performansu, akcji artystycznej, sztuki sitespecyfic czy sztuki ziemi. Okazało się także, że wiele z przyniesionych kamieni ma swoje ciekawe historie. W efekcie padła propozycja napisania krótkich form literackich związanych z historiami odnalezionych „ważnych” kamieni, która 
spodobała się większości studentów. Również w tym wypadku nie został przeze mnie określony precyzyjny czas powstania tekstów.

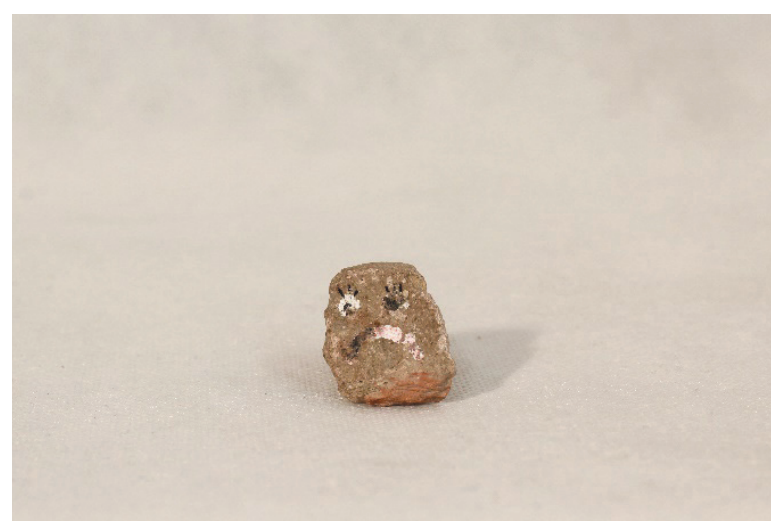

Fot. 2. „Smutny Kamień” - fot. Djana Berdak

\section{DZIEŃ TRZECI, CZWARTY I PIĄTY - KAMIENNE OPOWIEŚCI}

Kilka następnych warsztatów poświęcono czytaniu stworzonych przez studentów tekstów i rozbudowywaniu wokół nich koncepcji innych działań artystycznych. Nagromadzenie kilkudziesięciu utworów zaowocowało pomysłem stworzenia książki i działania artystycznego wychodzącego w przestrzeń publiczną. Początkowo tym dodatkowym działaniem miał być rodzaj performansu, w którym autorzy czytaliby jednocześnie swoje teksty w oznaczonym czasie w różnych lokalizacjach na terenie wydziału. W trakcie dyskusji nad sposobem realizacji tego zamiaru okazało się jednak, że być może dużo ciekawszym i bardziej - jak to określili studenci - „zagadkowym” rozwiązaniem będzie rozłożenie w przestrzeni wydziału wydrukowanych tekstów „ukrytych” pod kamieniami, tak, aby włączyć publiczność w działania artystyczne i wciągnąć ją w rodzaj interakcji z pogranicza geocatchingu i gry miejskiej. Część uczestników, która wcześniej nie wyraziła gotowości do tworzenia dzieł literackich, zaproponowała, że ich wkładem w grupowe działanie może być stworzenie dokumentacji fotograficznej i filmowej, stworzenie realizacji multimedialnej, wydarzenia w mediach społecznościowych oraz działania pomocnicze. 


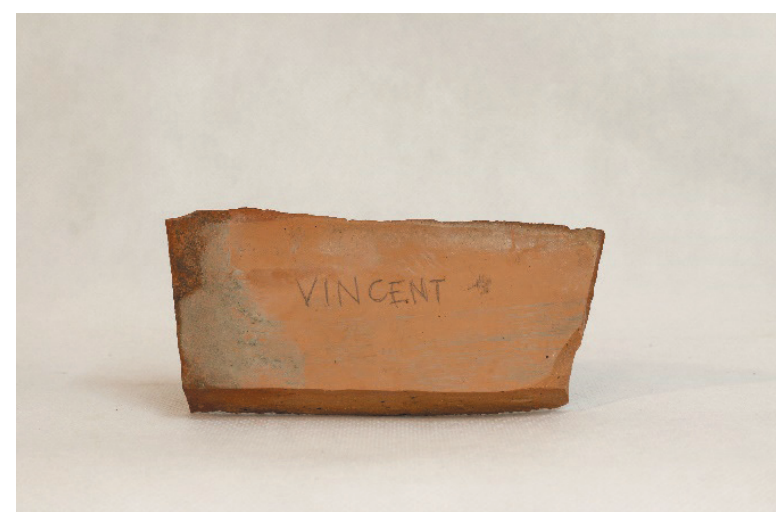

Fot. 3. Kamień „Vincent” - fot. Djana Berdak

W szóstym dniu warsztatu zastanawialiśmy się nad tym, jak zrealizować trudne przedsięwzięcie wydania książki. Wszak opublikowanie prawie 50 tekstów literackich to niemałe przedsięwzięcie edytorskie, logistyczne i ekonomiczne. $Z$ wielu różnych pomysłów, w demokratycznym głosowaniu, wybrana została koncepcja stworzenia wydawnictwa unikatowego, realizowanego własnymi siłami i środkami grupy.

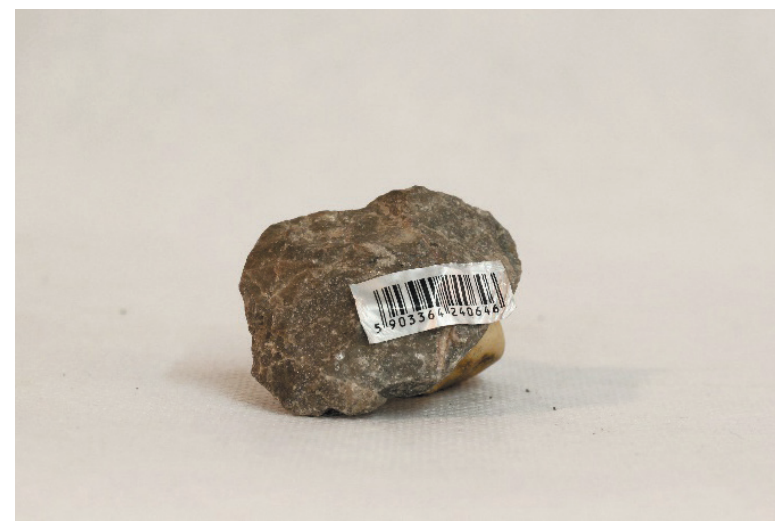

Fot. 3. Jeden z kamieni - fot. Djana Berdak 


\section{DZIEŃ SZÓSTY - KAMIEŃ, KAMERA, AKCJA}

Szóste spotkanie warsztatowe poświęcone było realizacji planu filmowego, która rozpoczęła się przedyskutowaniem formy, w jakiej zostanie zrealizowane wystąpienie każdej z chętnych osób i sposobu, w jaki się zaprezentuje. Studenci ustalili, że ujęcia filmowe zostaną ograniczone do ważnych z subiektywnego punktu widzenia autorów fragmentów napisanych przez nich tekstów, tak, aby zbędnie nie rozbudowywać narracji filmowej oraz zbliżeń i półzbliżeń budujących nastrój intymności i bezpośredniości wypowiedzi.

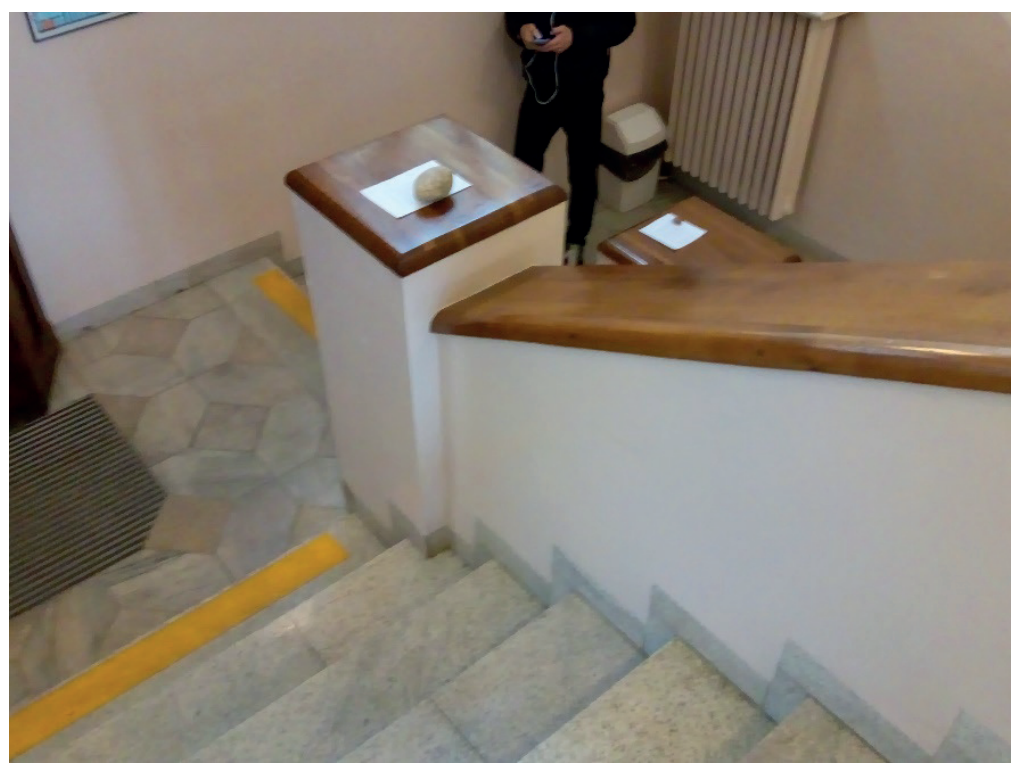

Fot. 3. „Geocatching” w murach wydziału - fot. Marcin Cabak

\section{DZIEŃ SIÓDMY - TYTUŁ WIEŃCZY DZIEŁO}

Książka powinna mieć swój tytuł. Jak jednak stworzyć ten najlepszy, najwymowniejszy, najlepiej oddający charakter i treść dzieła, a przynajmniej taki, który spodoba się całej grupie? Wszak tworzymy dzieło zbiorowe. Zaproponowałem studentom stworzenie go techniką , „alternatywnych tytułów” w wersji z burzą mózgów (Nęcka 2012, s. 124). Wygenerowanych zostało około 100 mniej lub bardziej oryginalnych pomysłów. W fazie czerwonego światła drogą eliminacji kolejnych pomysłów liczba ta została ograniczona do około dwudziestu, po czym ostateczny tytuł „Stoneowani” został wybrany w głosowaniu balotażowym. 


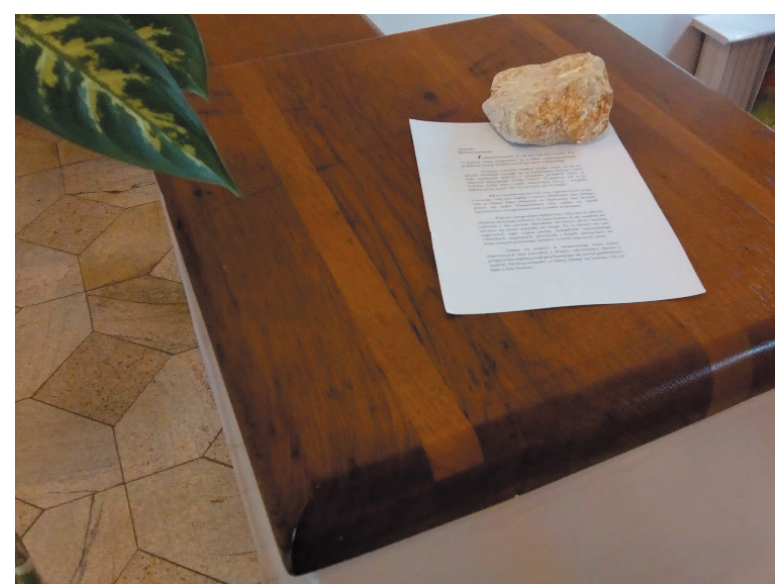

Fot. 3. „Geocatching” w murach wydziału - fot. Marcin Cabak

\section{DZIEŃ ÓSMY I DZIEWIĄTY - RZEMIEŚLNICZY TRUD}

Kiedy dyskutowaliśmy o przyszłym wyglądzie książki, studenci (niektórzy być może po raz pierwszy) uświadomili sobie, że typograficzne opracowanie wydawnictwa nie jest rzeczą łatwą i wymaga pewnych specjalistycznych umiejętności. Ponieważ opanowanie wiedzy typograficznej przez grupę w stopniu pozwalającym na samodzielne zaprojektowanie layoutu wymagałoby zrealizowania jeśli nie osobnego modułu, to w każdym razie cyklu spotkań, uznaliśmy, że zostanie on zaprojektowany przeze mnie, natomiast studenci złamią swoje teksty według wzoru, lecz samodzielnie. To była zresztą moja jedyna istotna interwencja w wygląd książki, dokonana jednak na wyraźną prośbę studentów.

Wydrukowane teksty zostały połączone na kolejnym - dziewiątym - warsztacie przy wykorzystaniu szwu japońskiego, którego znajomością podzieliła się z nami wcześniej jedna z uczestniczek.

Początkowo ustaliliśmy, że książeczka będzie ilustrowana fotografiami kamieni. Jednak studenci orzekli, że jakość uzyskanych wydruków pogarszałaby estetykę wydawnictwa, a zatem należy z nich zrezygnować. 


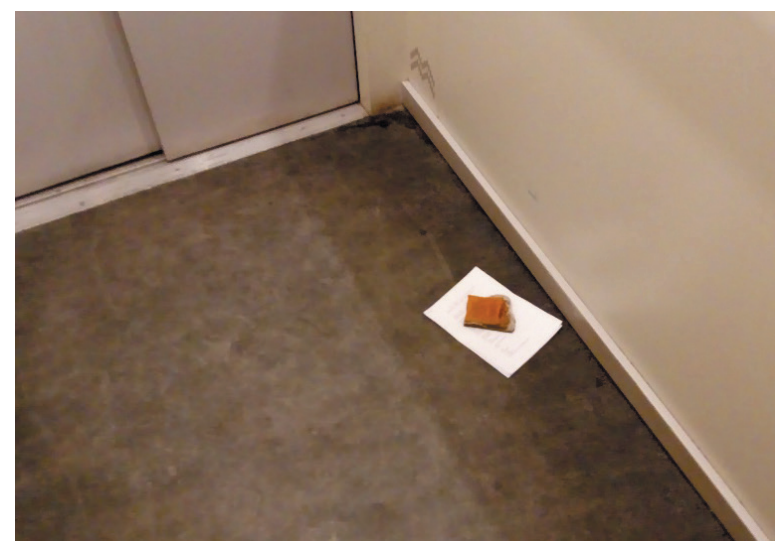

Fot. 3. „Geocatching” w murach wydziału - fot. Marcin Cabak

\section{OSTATNI, DZIESIĄTY DZIEŃ WARSZTATU - SPOTKANIE Z PUBLICZNOŚCIĄ}

Ostatniego dnia warsztatu studenci wkroczyli w przestrzeń wydziału rozkładając w różnych miejscach kartki z wydrukowanymi utworami literackimi. Ostatnim zadaniem, jakie podczas warsztatu wyznaczyli sobie studenci, było dyskretne obserwowanie reakcji publiczności. Z ich relacji wynika, że nieświadomi uczestnicy tej akcji artystycznej reagowali na odnajdowane kamienie i teksty zdziwieniem, zaciekawieniem, konsternacją, a nawet złością. Część osób (co było naszym zamiarem) dała się wciągnąć w grę i krążyła po wydziale „w poszukiwaniu skarbów”.

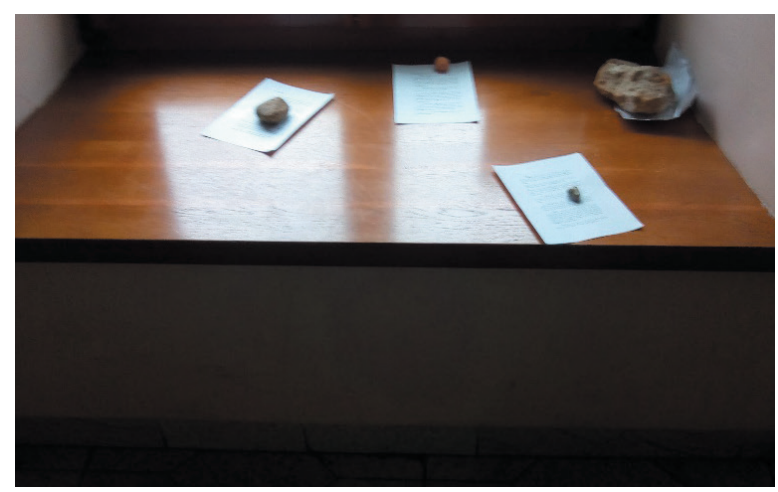

Fot. 3. „Geocatching” w murach wydziału - fot. Marcin Cabak 


\section{PODSUMOWANIE}

Pierwszym wnioskiem nasuwającym się w efekcie przeprowadzenia warsztatu jest to, że pomimo ograniczeń jakie narzuca sformalizowany charakter uczelni wyższej, warsztat twórczy jest metodą dydaktyczną, którą da się zastosować do edukacji artystycznej na wydziałach innych niż artystyczne. Rozwiązaniem znoszącym sprzeczność między postulatem dobrowolności udziału a obowiązkowym charakterem zajęć może być stosowanie warsztatu w ramach zajęć fakultatywnych. Można także szukać pewnego kompromisu, pozostawiając studentom swobodę wyboru formy aktywności, tak, aby przestały być przymusem, a wynikały z aktualnych możliwości i potrzeb poszczególnych osób. Z kolei aby wyzwolić się z okowów „dzwonkowego systemu" można tak umieścić warsztat w planie zajęć, aby swobodniej dysponować czasem. Pewną pozorną trudność może stwarzać pogodzenie nieoznaczoności ostatecznego rezultatu działań z założonymi z góry efektami kształcenia. Przeszkoda ta jednak znika, jeśli uświadomimy sobie, że drogą do ich osiągnięcia nie jest uzyskanie ściśle wyznaczonego wytworu, lecz zainicjowanie określonego procesu.

Wspomniana wcześniej „przezroczystość” prowadzącego czy demokratyzm relacji także nie wydaje się kłócić $\mathrm{z}$ akademickim duchem, a odnosić do tradycji. Trywialnym będzie stwierdzenie, że studia są okazją do samodzielnego zdobywania wiedzy. Z kolei demokratyczny styl nauczania jest uważany za pożądany (np. Śnieżyński 1984, s. 257).

Warsztat twórczy wykorzystany jako metoda dydaktyczna jest niewątpliwie wymagający i stawia przed wykładowcą, inicjatorem, prowadzącym szereg wyzwań, których nie nastręczają inne. Jak podkreślają praktycy (zob. np. Józefowski, Bałdyga, Olinkiewicz i inni) - i co stało się także doświadczeniem autora - prowadzący warsztaty powinien posiadać szeroką wiedzę tematyczną, szereg konkretnych cech osobowościowych i kompetencji społecznych. Wiele z postulowanych przez praktyków warunków konstytutywnych dla warsztatu artystycznego na wydziałach nieartystycznych może być trudnych do spełnienia. Jeśli jednak wziąć pod uwagę jego aktywizujący, osobowościowo twórczy potencjał, nastawienie na wieloaspektowy, podmiotowy rozwój, a także artystyczne i edukacyjne możliwości, sądzę, że powinien stać się metodą szerzej stosowaną.

PRZYKŁADOWE UTWORY LITERACKIE POWSTAŁE W WYNIKU WARSZTATU

\section{Oleksandra Orkusha}

Znalazłam swój kamień, kiedy odpoczywałam nad Morzem Czarnym na Krymie. Ze wszystkich kamieni na plaży, tylko ten jakby mówił do mnie ,Jestem wyjątko- 
wy, weź mnie ze sobą". Tak i w życiu odnajdujemy z tłumu jednego wyjątkowego człowieka, który powinien być z tobą.

\section{Diana Berdak}

Ludzie zwykle nie zwracają uwagi na tak drobne szczegóły, jak chociażby łączenie płyt chodnikowych czy kompozycja przedmiotów codziennego użytku. Ja zaś mam wrażenie, że widzę każdy najmniejszy szczegół.

Mój kamień znalazłam niedaleko mojej stancji. Wracając z zajęć, zauważyłam zadbaną posesję wraz z przykuwającym uwagę ogrodzeniem. Mój wzrok przykuł kamień leżący przy ogrodzeniu, który zaburzał całą harmonię i porządek.

Jestem nietypowym człowiekiem, więc postanowiłam usunąć go z tego miejsca, abym mogła dalej w spokoju ducha kontynuować swój spacer. Kamień zabrałam ze sobą i co dziwne utożsamiam się z nim.

Zachwyca mnie swoją różnorodnością. Można powiedzieć, że posiada on dwa oblicza. Pierwsze - ciemne o gładkiej fakturze, drugie za to jaśniejsze o nieregularnych ostrzejszych kształtach. Dokładnie tak samo człowiek ma swoje odmienne oblicza.

W moim znalezisku zatopione są cząstki innych kamieni, dla mnie symbolizują one przeżycia i doświadczenie, jak również osoby napotkane na naszej drodze.

Kamień ma zaostrzone końce, co dla mnie oznacza determinację i wyraża mój charakter. W każdym szczególe odnajduję nawiązanie do mojego życia.

Myślę, że znalezienie tego kamienia nie było przypadkowe. W końcu nic nie dzieje się bez powodu!

\section{Anna Śmielak}

Przyjechałam w weekend samochodem do Lublina. Niestety w okolicy, w której mieszkam, nie ma wielu miejsc, żeby zaparkować. Po kilkunastu minutach udało mi się znaleźć miejsce. Niestety, było to miejsce strome, na górce. W związku z tym, że mój hamulec ręczny nie spełnia do końca swoich funkcji, postanowiłam, że podłożę kamień pod oponę z przodu, żeby samochód przypadkiem w nocy się nie stoczył. Okazało się, że był to dobry pomysł. Od tamtej pory zwykły „kamień” stał się dla mnie czymś istotnym.

\section{PODZIĘKOWANIA}

Pragnę podziękować autorom prezentowanych w niniejszym artykule tekstów literackich i fotografii za użyczenie mi praw autorskich. 


\section{LITERATURA}

Bałdyga J., 2001, Projekt warsztatowy: ze sztuka wobec sztuki. W: Olinkiewic E. (red.) Warsztaty edukacji twórczej. Wydawnictwo Europa.

Bałdyga J., 2016, PRACOWNIA/WARSZTAT Sztuka performance. Perspektywiczne i syntetyczne strategie edukacyjne. Poznań, Uniwersytet Artystyczny w Poznaniu.

Berdyszak J., Warsztaty, kreacja, edukacja. W: Olinkiewic E. (red.) Warsztaty edukacji twórczej. Wydawnictwo Europa.

Berleant A., 2007, Prze-myśleć estetykę, Wyd. Universitas, Kraków.

Buchner A., Maryl M., 2016, Nowi literaci. Warsztat twórczy blogerów w kontekście współczesnych przemian kultury literackiej. W: W. Doliński, J. Żurko, K. Grzeszkiewicz-Radulska, S. Mecfal (red.), Rzeczywistość i zapis. Problemy badania tekstów $w$ naukach społecznych i humanistycznych. Łódź, Wydawnictwo Uniwersytetu Łódzkiego.

Byszewski J., 2001, Tutaj jestem. W: Olinkiewic E. (red.) Warsztaty edukacji twórczej. Wydawnictwo Europa.

Józefowski E. Florczykiewicz J., 2013, Warsztat twórczy jako forma działania artystycznego w przestrzeni sztuki. Wybrane aspekty teoretyczne i studium empiryczne. W: Reguska A. (red.) Media w edukacji. Obszary lokalności - różnorodność współczesności, Fundacja na rzecz dzieci i młodzieży „SZANSA”, Siedlce.

Józefowski E. Florczykiewicz J., 2015a, Warsztat twórczy jako okazja rozwoju podmiotowego w przestrzeni sztuki, Wrocław, Drukarnia Jaks.

Józefowski E. Florczykiewicz J., 2015b, Warsztat twórczy jako obszar poszerzania samowiedzy - metodyczne aspekty pedagogiki inkluzyjnej. Student Niepełnosprawny $\mathrm{Nr} 15(8)$

Józefowski E., 2009, Edukacja artystyczna w działaniach warsztatowych. Łódź, Wydawnictwo Akademii Humanistyczno-Ekonomicznej w Łodzi.

Nęcka E., 2012, Trening twórczości, Sopot, Wydawnictwo GWP.

Olinkiewicz E., 2001, Warsztat - co to takiego? W: Olinkiewic E. (red.) Warsztaty edukacji twórczej. Wydawnictwo Europa.

Olinkiewicz E., 2001, ... kreacją. Warsztaty działań twórczych. W: Olinkiewic E. (red.) Warsztaty edukacji twórczej. Wydawnictwo Europa.

Śnieżyński A, 1984, Nauczanie aktywizujące, Kraków, Wydawnictwo Naukowe WSP. Wawrzyniak M., 2002, Aleksytymia i neurotyzm; różnicowanie i werbalizacja emocji podstawowyc. „Przegląd Psychologiczny”, t. 45, nr 1, 109-122. 


\title{
CREATIVE WORKSHOP AS A METHOD OF ARTISTIC EDUCATION \\ AT NON-ARTISTIC FACULTIES
}

\begin{abstract}
This article discusses the role of a didactic method called Creative Workshop in the artistic education of students at non-artistic faculties. The first part of the article is an analysis of the term Creative Workshop. The origins, history and the place of the Creative Workshp method in the art domain is discussed. Specifics of using this method at non-artistics faculties are also presented. The second part describes workshops which took place at an university with an non-artistic profile. The third part contains conclusions. The fourth part presents examples of works created during workshops.
\end{abstract}

Keywords: creative workschop, didactics,didactic methods 